\title{
Educational Tourism in Malaysia: Implications for Community Development Practice
}

\author{
Asnarulkhadi Abu Samah ${ }^{1} \&$ Maryam Ahmadian ${ }^{1}$ \\ ${ }^{1}$ Department of Social and Development Sciences, Faculty of Human Ecology, Universiti Putra Malaysia (UPM), \\ Malaysia
}

Correspondence: Maryam Ahmadian, Department of Social and Development Sciences, Faculty of Human Ecology, Universiti Putra Malaysia (UPM) 43400, Malaysia. E-mail: maryam_ahmadian@upm.edu.my

Received: May 27, 2013 Accepted: July 25, 2013 Online Published: August 30, 2013

doi:10.5539/ass.v9n11p17 URL: http://dx.doi.org/10.5539/ass.v9n11p17

\begin{abstract}
Background: This paper aims to discuss the impacts of educational tourism on the residents in the Klang Valley, Malaysia. Educational tourism is a means to empower educational communities, host communities, local entrepreneurs, and to enhance economic prosperity. Method: A cross-sectional survey was carried out in five districts in Selangor and Kuala Lumpur (Federal Territory) which are located in the Klang Valley, and Nilai, Negeri Sembilan. Data was collected from 700 respondents using structured questionnaire from the Klang Valley and Nilai. Results: Pearson correlation analysis revealed that, there is significant positive moderate relationship between attitude, environmental impact, economic impact, and socio-cultural impact and practice. Multiple linear regressions showed that socio-cultural and economic impact of educational tourism, and local community attitude has significantly contributed to residents' practice to educational tourists in the Klang Valley. Conclusion: The findings propose new insights into the socio-cultural and economic impacts of educational tourism and community development practice. Educational tourism can sustain the development of career paths for workers and local communities. The results of this study present practical information on sustainable educational programs for both the Ministry of Higher Education and the Ministry of Tourism.
\end{abstract}

Keywords: community development, educational tourism impacts, attitude, practice

\section{Introduction}

Educational tourism has been recognized as a new industry in South-East Asia, particularly in Malaysia. In order to enhance tourism development, educational tourism program was acknowledged as one of the tools to improve national tourism, which was developed by the Ministry of Culture, Arts and Tourism and the Ministry of Education in 2001 (Hamzah, 2004). The significant contribution of educational tourism to the Malaysian economy makes it necessary for the government to recognize the relevance of the industry (Nair \& Whitelaw, 2008). As indicated by Lam et al., (2011), in recent decades the growth of educational tourism has led to the perception of this industry from both social and economic point of view. Moreover, Ankomah and Lawson (2002) stated that, countries which are capable of making educational tourism industry as an avenue for international learning exchange program could be more successful. Because the combination of tourism and education over the past few decades has significantly improved the performance of this industry with facilitation of education and learning which is becoming the main target of educational tourists (Lam et al., 2011).

Therefore, Educational tourism can be defined as a program which the potential learners move to a certain location with the aim of acquiring a new knowledge related to their discipline (Bodger, 1998). Educational tourism is a process which enhances socio-economic capital, and empowerment for learners and host communities worldwide (Pittman, 2003). Similarly, Ritchie et al., (2003) argued that educational tourism is mainly an activity engaged by people who are having an overnight visit and those who are undertaking an excursion as education and learning are primary or secondary part of their journey.

Previous studies have been conducted to investigate the impacts of tourism development from the host communities' perspective (Belisle \& Hoy, 1980; Ap, 1992; King et al., 1993; Jurowski e al., 1997; Lindberg \& Johnson, 1997; Liu \& Var, 1986). While several surveys have been carried out on the host perceptions towards tourism development, however, little functional research has been done on educational tourism development and its impacts on the local residents. Host communities' perception may show variation in their attitude and practice 
to educational tourism development. Sirakaya et al. (2008) indicated that policy makers and marketers may benefit from a better perspective of residents toward sustainable tourism. Furthermore, previous researchers considered several factors to measure residents' perceptions of tourism impacts such as social, environmental, and economic impacts (Sirakaya et al., 2001; Ko \& Stewart, 2002; Gursoy et al., 2002; Yu et al., 2011; Samah et al., 2012).

In this paper, the authors aimed to examine the implications of educational tourism in relation to host communities. Based on this, authors proposed the following statement; the selected dimensions of educational tourism impacts and residents' attitude would have relationship with residents' practice in the Klang Valley, Malaysia, and the regression coefficients for all independent variables are significant when regressed against community practice. A case study on the residents' responses towards educational tourism impacts in the Klang Valley would lead to a better quality of life which is important to the development of local communities in Malaysia. For this study 'educational tourists' refers to international students who moved to Malaysia with the aim to engage in learning process in both public and privates universities. And then the term 'local resident'/ 'host community' or 'dweller' refers to the residents who live near the educational institutes in the Klang Valley and Nilai districts.

\section{Methods}

A non-random cross-sectional survey design was employed and data was collected from 700 respondents from five districts in Selangor namely; Bangi, Petaling Jaya, Serdang, Gombak and Shah Alam, Kuala Lumpur, and Nilai. In this study 'the Klang Valley' refers to all study areas. A multi-dimensional questionnaire was developed to examine residents' perceptions of educational tourism impacts in the Klang Valley, Malaysia. Most of the items in the questionnaire were adopted from previous literature which had showed high reliability coefficients. In-depth interviews were carried out with different stakeholder groups to help in constructing the questionnaire before a pilot study. Results reported have been published elsewhere (Abu Samah et al., 2012). All items were measured using a 5-point Likert-scale, ranging from strongly disagree $=1$ to strongly agree $=5$. Data analysis was completed using SPSS version 20.0 (SPSS, Inc., Chicago, IL).

\section{Results}

The descriptive analysis in table 1 shows that out of the 700 respondents, males constitute $60.4 \%$ and females were $39.6 \%$. With regards to level of education, about $51.6 \%$ of the respondents attended high school, $18.9 \%$ attended colleges, $18 \%$ have bachelor degree, $6.6 \%$ have graduate degree and $5 \%$ attended elementary school only. This means those who attended high school were the majority among the respondents. Similarly, Malay constitutes the majority of the respondents (77.3\%), followed by Chinese (12\%) and lastly Indians $(9.7 \%)$. Regarding religion affiliations, Muslims were the majority with $78.7 \%$, followed by Buddha $9 \%$, Hindu $7 \%$ and Christian $4.4 \%$. Employers in industrial services constitute the majority of the respondents $39.7 \%$, marketers $34.9 \%$, professionals $11 \%$, clerical employees $5.3 \%$, administrators $3.9 \%$, and operators $1.6 \%$ only. However, $3.7 \%$ of the respondents are unemployed. 
Table 1. Demographic variables $(\mathrm{n}=700)$

\begin{tabular}{|c|c|c|}
\hline Variables & Frequency & Percentage (\%) \\
\hline \multicolumn{3}{|l|}{ Gender } \\
\hline male & 423 & $60.4 \%$ \\
\hline Female & 277 & $39.6 \%$ \\
\hline \multicolumn{3}{|l|}{ Level of Education } \\
\hline Elementary school & 35 & $5 \%$ \\
\hline Middle school & 361 & $51.6 \%$ \\
\hline College & 132 & $18.9 \%$ \\
\hline Bachelor degree & 126 & $18 \%$ \\
\hline Graduate degree & 46 & $6.6 \%$ \\
\hline \multicolumn{3}{|l|}{ Race } \\
\hline Malay & 541 & $77.3 \%$ \\
\hline Chinese & 84 & $12 \%$ \\
\hline Indian & 68 & $9.7 \%$ \\
\hline others & 7 & $1 \%$ \\
\hline \multicolumn{3}{|l|}{ Religion } \\
\hline Islam & 551 & $78.7 \%$ \\
\hline Buddha & 63 & $9 \%$ \\
\hline Christian & 31 & $4.4 \%$ \\
\hline Hindu & 53 & $7.6 \%$ \\
\hline Others & 2 & $0.3 \%$ \\
\hline \multicolumn{3}{|l|}{ Occupation } \\
\hline Administration & 27 & $3.9 \%$ \\
\hline Clerical & 37 & $5.3 \%$ \\
\hline Marketing & 244 & $34.9 \%$ \\
\hline Not working & 26 & $3.7 \%$ \\
\hline Operators & 11 & $1.6 \%$ \\
\hline Professionals & 77 & $11 \%$ \\
\hline Services Industries & 278 & $39.7 \%$ \\
\hline
\end{tabular}

The Pearson correlation analysis was conducted to examine the relationships between attitude, environmental, economic, socio-cultural impact, and practice. As shown in table 2, there is significant positive moderate relationship between attitude and socio-cultural impact $(\mathrm{r}=.401, \mathrm{p}<.01)$, there is significant positive moderate relationship between environmental impact and socio-cultural impact $(\mathrm{r}=.349, \mathrm{p}<.01)$, there is significant positive moderate relationship between economic impact and socio-cultural impact $(\mathrm{r}=.447, \mathrm{p}<.01)$, and there is significant positive moderate relationship between practice and socio-cultural impact $(\mathrm{r}=.366, \mathrm{p}<.01)$. 
Table 2. Pearson correlation between independent variables and community practice

\begin{tabular}{llllll}
\hline Variables & $\begin{array}{l}\text { Socio-cultural } \\
\text { impact }\end{array}$ & Attitude & $\begin{array}{l}\text { Environmental } \\
\text { impact }\end{array}$ & $\begin{array}{l}\text { Economic } \\
\text { impact }\end{array}$ & Practice \\
\hline $\begin{array}{l}\text { Socio-cultural impact } \\
\text { Attitude }\end{array}$ & $.401^{* *}$ & 1 & & & \\
$\begin{array}{l}\text { Environmental } \\
\text { impact }\end{array}$ & $.349^{* *}$ & $.286^{* *}$ & 1 & \\
Economic impact & $.447^{* *}$ & $.368^{* *}$ & $.374^{* *}$ & 1 & \\
Practice & $.366^{* *}$ & $.393^{* *}$ & $.236^{* *}$ & $368^{* *}$ & 1 \\
\hline
\end{tabular}

Note. ${ }^{* *}$ Correlation is significant at the 0.01 level (2-tailed).

The summary ANOVA in table 3 illustrates the multiple regression model of community practice. The results of the multiple linear regression analysis as a whole is significant $(\mathrm{F}(4,695)=53.835, \mathrm{P}=.000)$ which means the model fits the data. This indicated that the slope of the estimated linear regression model line is not equal to zero. Therefore, the proposed hypothesis is supported.

Table 3. Summary ANOVA table

\begin{tabular}{llllll}
\hline Model & Sum Square & df & Mean Square & F & Sig. \\
\hline Regression & 49.650 & 4 & 12.413 & 53.835 & $.000^{\mathrm{a}}$ \\
Residual & 160.245 & 695 & .231 & & \\
Total & 209.895 & 699 & & & \\
\hline
\end{tabular}

a) Predictors: (Constant), environmental-mean, attitude-mean, economic-mean, socio-cultural-mean

b) Dependent Variable: community practice-mean

The multiple regression coefficients generated by SPSS shows that, about $24.1 \%$ variance in community practice was explained by all the predictor variables entered into the regression model. The analysis shown that three independent variables, namely, socio-cultural impact $(\beta=.172, \mathrm{t}=4.371, \mathrm{p}=.000)$, attitude $(\beta=.244, \mathrm{t}=6.515$, $\mathrm{p}=.000)$ and economic impact $(\beta=.188, \mathrm{t}=4.812, \mathrm{p}=.000)$ has contributed significantly to community practice. However, environmental impact $(\beta=.036, \mathrm{t}=.979, \mathrm{p}=.328)$ does not contribute significantly to community practice. In addition, attitude has the highest beta coefficient, followed by economic impact and lastly socio-cultural impact (see table 4).

Table 4. Multiple linear regression on community practice

\begin{tabular}{llllll}
\hline \multirow{2}{*}{ Model } & \multicolumn{2}{l}{$\begin{array}{l}\text { Unstandardized } \\
\text { Coefficients }\end{array}$} & $\begin{array}{l}\text { Standardized } \\
\text { Coefficients }\end{array}$ & t & Sig. \\
& $\mathbf{B}$ & Std. Error & Beta $(\boldsymbol{\beta})$ & & \\
\hline (Constant) & 19.721 & 2.638 & & 7.282 & .000 \\
Socio-Cultural Impact & .214 & .074 & .172 & 4.371 & .000 \\
Attitude & .193 & .067 & .244 & 6.515 & .000 \\
Economic impact & .145 & .065 & .188 & 4.812 & .000 \\
Environmental impact & .031 & .052 & .036 & .979 & .328 \\
$\mathbf{R}^{2}=\mathbf{0 . 2 4 1}$, adjusted $\mathbf{R}^{\mathbf{2}=\mathbf{0 . 2 3 6}}$ & & & & & \\
\hline
\end{tabular}




\section{Discussion}

The results of multiple linear regression analysis revealed that residents' attitude, socio-cultural and economic impacts of educational tourism contributed significantly to residents' practice. The dwellers in the Klang Valley reported that the positive economic impact of international students influence the Malaysian economy and the establishment of more opportunities for local residents. Obviously, previous studies proved that practices towards tourism involve tourism development and improve quality of life (Perdue et al., 1990; McCool \& Martin, 1994; Andereck \& Vogt, 2000). In contrast, residents' perception of environmental impact of educational tourism did not have any significant contribution to residents' practice.

The local communities and their support are important for government's policies to the development of educational tourism. The results suggested that the educational tourism officials and entrepreneurs should focus on understanding different aspects of educational tourism in Malaysia. For example, factors such as economic benefits to local people, small businesses, and employment opportunities may directly influence residents' interaction with international students in their neighborhood. In addition, residents' practice was significantly influenced by socio-cultural factors in the Klang Valley, Malaysia. In other words, cultural factors help them to learn more about other traditions. The significant positive relationship between economic and socio-cultural impacts of educational tourism has resulted to positive attitudes among residents in the Klang Valley, Malaysia. In fact, the results indicated that socio-cultural impact, economic impact, and local community attitudes towards educational tourism is playing a significant role on residents' communication with international students (Samah et al., 2012).

The descriptive result shows the distributions of socio-demographic factors of the respondents in which majority of them were males. The findings revealed that majority of the respondents were employed in industry's services, and this is in line with their low level of education in which most of them attended high school with very few who has bachelor and graduate degree. Although some of the respondents' occupations appears to be related to certain dimensions of perceived impacts such as economic impacts. In addition, Malay-Muslims constitute the majority among the respondents compared to Chinese-Buddha and Indian-Hindu respectively.

Therefore, analysis should be required for theory testing research beyond the scope of this paper. Other insights can be achieved through qualitative methods such as in-depth interview with residents and stakeholders who are in charge of educational tourism in Malaysia (Samah et al., 2012). What is happening in the educational tourism has important implications for the other sectors of tourism.

It is pertinent to say that policy makers may also not be aware of negative impacts of educational tourism at the local level. The residents and host communities also may not be of aware policy makers' goals for sustainable tourism programs. Consequently, a balance can be attained between tourism stakeholders and local communities through their interactions in order to enhance educational tourism development (Samah et al., 2012).

Above all, it is claimed that tourism projects did not benefit from full harmonization between local and tourism planners (Jenkins, 1982). Therefore, the role of local communities and their perceived tourism impacts in determining tourism policies cannot be ignored. For this reason, local community participation in tourism development can serve as a tool to facilitate its process and improves the community quality of life.

Community participation as a multidimensional phenomenon does not only need tourism planners, but also sociologists, economists, social psychologists and political scientists with some prior knowledge of tourism (Tosun, 2000). In addition, the future research interest should be to assess the effects of local community participation in educational tourism development and the role of cultural attributes of communities. Countries such as Malaysia should respond to the need of local communities whether socio-cultural or economic needs by implementing tailored programs on tourism development. By doing so, educational tourism development may contribute to better community's quality of life, thus, it is part of developing the community.

\section{Conclusion}

This paper proposes that educational tourism impacts and the residents' positive attitudes can influence their practices to educational tourism development in host communities. However, we suggest more studies to further confirm these results. The findings also suggested that the educational tourism development is related to certain dimensions of tourism impacts on host communities. Educational tourism managers and entrepreneurs should reconsider these impacts to ensure local community (residents/citizen) participation in educational tourism development. It should be noted that implementing educational tourism programs requires an adjustment in socio-cultural, environmental, and economic structure of host communities which help to build their capacity to engage in the development of educational tourism planning. Indeed, the above argument and suggestion cannot 
be met easily; however, the contribution of study results has provided a valuable perspective on community development and tourism.

\section{Acknowledgment}

We would like to express our sincere appreciation to the Universiti Putra Malaysia (UPM) for providing us the grant (Project No: 0604101015RU) for this study.

\section{References}

Andereck, K. L., \& Vogt, C. A. (2000). The relationship between residents' attitudes toward tourism and tourism development options. Journal of Travel research, 39, 27-36. http://dx.doi.org/10.1177/004728750003900104

Ankomah, P. K., \& Lawson, R. T. (2002). Education tourism: A strategy to sustainable tourism development in sub-Saharan Africa. Retrieved June 2, 2010, from http: //unpan1.un.org/intradoc/groups/public/documents/idep/unpan002585.pdf

Ap, J. (1992). Residents' perceptions on tourism impacts. Annals of Tourism Research, 19(4), 665-690. http://dx.doi.org/10.1016/0160-7383(92)90060-3

Belisle, F. J., \& Hoy, D. R. (1980). The perceived impact of tourism by residents. Annals of Tourism Research, 7 , 83-101. http://dx.doi.org/10.1016/S0160-7383(80)80008-9

Bodger, D. (1998). Leisure, learning, and travel. Journal of Physical Education Recreation \& Dance, 69(4), 28-31. http://dx.doi.org/10.1080/07303084.1998.10605532

Gursoy, D. J., Jurowski, C., \& Uysal, M. (2002). Resident Attitudes: Structural Modeling Approach. Annals of Tourism Research, 29(1), 79-105. http://dx.doi.org/10.1016/S0160-7383(01)00028-7

Hamzah, A. (2004). Policy and planning of the tourism industry in Malaysia. The 6th ADRF general meeting, Bangkok, Thailand.

Jenkins, C. L. (1982). The Effects of Scale in Tourism Projects in Developing Countries. Annals of Tourism Research, 9(2), 229-250. http://dx.doi.org/10.1016/0160-7383(82)90047-0

Jurowski, C., Uysal, M., \& Williams, D. R. (1997). A theoretical analysis of host community resident reactions to tourism. Journal of Travel Research, 36(2), 3-11.

King, B., Pizam, A., \& Milman, A. (1993). Social impacts of tourism: Host perceptions. Annals of Tourism Research, 20, 650-655. http://dx.doi.org/10.1016/0160-7383(93)90089-L

Ko, D. W., \& Stewart, W. P. (2002). A Structural Equation Model of Residents Attitudes for Tourism Development. Tourism Management, 23, 521-530. http://dx.doi.org/10.1016/S0261-5177(02)00006-7

Lam, J. M. S., Ariffin, A. A., \& Ahmad, A. (2011). Edutourism: exploring the push-pull factors in selecting a university. International Journal of Business and Society, 12(1), 63-78.

Lindberg, K., \& Johnson, R. L. (1997). Modeling resident attitudes toward tourism. Annals of Tourism Research, 24(2), 402-424. http://dx.doi.org/10.1016/S0160-7383(97)80009-6

Liu, J. C., \& Var, T. (1986). Residents attitudes toward tourism impacts In Hawaii. Annals of Tourism Research, 13, 193-214. http://dx.doi.org/10.1016/0160-7383(86)90037-X

McCool, S. F., \& Martin, S. R. (1994). Community attachment and attitudes towards tourism development. Journal of Travel Research, 32(3), 29-34. http://dx.doi.org/10.1177/004728759403200305

Nair, V., \& Whitelaw, P. (2008). Hospitality and Tourism Vocation: Program Selection in a Private Institution of Higher Learning in Malaysia. Journal of Hospitality and Tourism Education, 20(3), 30-34. http://dx.doi.org/10.1080/10963758.2008.10696920

Perdue, R. R., Long, P. T., \& Allen, L. (1990). Resident support for tourism development. Annals of Tourism Research, 17(4), 586-599. http://dx.doi.org/10.1016/0160-7383(90)90029-Q

Pittman, J. (2003). Empowering individuals, schools, and communities. In: Solomon G, Allen N, Resta P (Eds), Toward digital equity: Bridging the divide in education.

Ritchie, B., Carr, N., \& Cooper, C. (2003). Managing Educational Tourism. Clevedon: Channel View Publications.

Samah, A. A., Ahmadian, M., Gill, S. S., \& Hendijani, R. B.(2012). Factors Affecting Educational Tourism Development among Local Communities in the Klang Valley, Malaysia. Life Science Journal, 9(4). 
Sirakaya, E., Ekinci, Y., \& Kaya, A. G. (2008). An Examination of the Validity of SUS-TAS in Cross-Cultures. Journal of Travel Research, 46(4), 414-421. http://dx.doi.org/10.1177/0047287507308328

Sirakaya, E., Jamal, T., \& Choi, H. S. (2001). Developing Indicators for Destination Sustainability. In D. B. Weaver, The Encyclopedia of Ecotourism, 411-432. New York: CAB International.

Tosun, C. (2000). Limits to community participation in the tourism development process in developing countries. Tourism management, 21(6), 613-633. http://dx.doi.org/10.1016/S0261-5177(00)00009-1

Yu, C. P., Chancellor, H. C., \& Cole, S. T. (2011). Measuring residents' attitudes toward sustainable tourism: a re-examination of the sustainable tourism attitude scale. Journal of Travel Research, 50(1), 57-63. http://dx.doi.org/10.1177/0047287509353189

\section{Copyrights}

Copyright for this article is retained by the author(s), with first publication rights granted to the journal.

This is an open-access article distributed under the terms and conditions of the Creative Commons Attribution license (http://creativecommons.org/licenses/by/3.0/). 